\title{
The Effect of Oxygen Impurity on High Temperature Thermal Conductivity of AIN
}

\author{
By \\ Takaho TANAKA, Toshikazu SAKAI and Minoru IWATA \\ (National Institute for Researches in Inorganic Materials)
}

窒化アルミニウムの高温熱伝導度に対する酸素不純物の影響

\author{
田中高穂・酒井利和・岩田 稔 \\ (科学技術庁 無機材質研究所)
}

The effect of oxygen impurity on thermal conductivity of aluminum nitride was studied at high temperatures.

Powder materials of aluminum nitride were synthesized by Serpek's method ${ }^{1 / 2)}$, i.e. aluminum oxide was reduced by carbon in a nitrogen atmosphere. Specimens for measurements were obtained by hot-pressing. The characteristics of the specimens are tabulated in Table 1 . The oxygen contents of the specimens were determined by fast neutron activation analysis.

The thermal conductivity was measured by the modulated electron beam technique. Experimental details and the deduction of thermal conductivity are the same as described in the previous works ${ }^{3), 4)}$.

The thermal conductivities obtained are shown in Fig. 1. The specimen of lowest oxygen content shows the lowest thermal conductivity and it is probably due to its lowest density. So the thermal conductivity was corrected to zero porosity by a next equation,

$$
k_{0}=\frac{k}{1-P}
$$

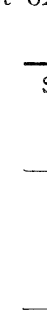

\begin{tabular}{|c|c|c|c|c|c|c|c|}
\hline \multirow{2}{*}{$\begin{array}{c}\text { Specimen } \\
\text { R-3D }\end{array}$} & \multirow{2}{*}{$\begin{array}{c}\begin{array}{c}\text { Average size } \\
\text { of powder } \\
(\mu \mathrm{m})\end{array} \\
0.2\end{array}$} & \multicolumn{3}{|c|}{$\begin{array}{l}\text { Condition of hot- } \\
\text { pressing } \\
\left(\mathrm{kg} / \mathrm{cm}^{2}{ }^{\circ} \mathrm{C} \mathrm{min}\right)\end{array}$} & \multirow{2}{*}{$\begin{array}{c}\text { Density } \\
\left(\mathrm{g} / \mathrm{cm}^{3}\right)\end{array}$} & \multirow{2}{*}{$\begin{array}{l}\text { Oxygen content } \\
\text { of powder } \\
\text { (wt } \%)\end{array}$} & \multirow{2}{*}{$\begin{array}{c}\begin{array}{c}\text { Oxygen content } \\
\text { after hot-pressing } \\
\text { (wt } \%)\end{array} \\
4.2\end{array}$} \\
\hline & & 200 & 1800 & 40 & & & \\
\hline R-4 & 0.6 & 200 & 1800 & 40 & 3.04 & 6.68 & 4.49 \\
\hline R-5 & 2.5 & 450 & 1900 & 120 & 2.35 & 1.63 & 0.94 \\
\hline $\mathrm{R}-6$ & 0.4 & 200 & 1800 & 120 & 3.24 & 7.22 & 2.86 \\
\hline
\end{tabular}

where $P$ is the porosity of specimen and $k_{0}$ and $k$ are the zero porosity thermal conductivity and the measured thermal conductivity, respectively.

The results are shown in Fig. 2. There seems to be no apparent correlation between the oxygen "content and the thermal conductivity. Therefore one can consider that the thermal conductivity of aluminum nitride at high temperature is not influenced by the oxygen impurity. Slack has found $a_{*}$ correlation between the oxygen content and the thermal conductivity of aluminum nitride at room temperature ${ }^{5)}$. According to the theory of lattice thermal conductivity, the effect of impurities on thermal conductivity becomes much stronger as the temperature decreases. So the present result and that of Slack may not necessarily contradict each other.

On the other hand, the thermal conductivity of present measurements is about two times higher than that of previous measurements ${ }^{3}$ and is rather close to that of Taylor and Lenie ${ }^{6}$. They used the specimen of $98 \%$ of theoretical density made by hot-pressing. In the previous experiment, the specimens were obtained by sintering and were $83 \%$ to $95 \%$ of theoretical density. The specimens of the present measurement were hot-pressed and were $72 \%$ to $99 \%$ of theoretical density. Therefore the differences of thermal conductivity of each$$
\text { TEMPEATURE ( } \left.{ }^{\circ} \mathrm{C}\right)
$$

Fig. 1. The thermal conductivity of aluminum nitride specimens vs. temperature. 


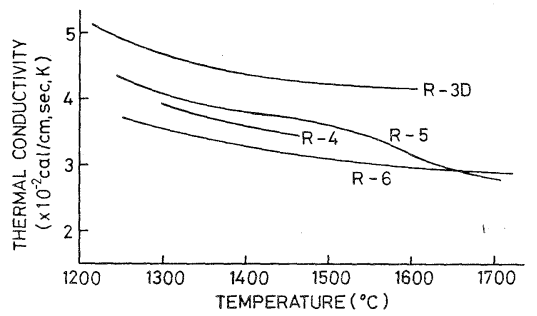

Fig. 2. The thermal conductivity corrected to zero porosity vs. temperature.

specimen may due to the differences of microstructure, such as crystallite size, pore shape and the width of grain boundary. To clarify this correlation, further experiments should be needed.

\section{References}

1) O. Serpek, Zeit. komp. Alüss. Gase 16, 55 (1914), Zeit. angew. Chem. 27, 41 (1914).

2) T. Sakai and M. Iwata, to be published.

3) T. Tanaka and H. Suzuki, Yogyo-kyokai-shi 78, 174-75 (1970).

4) T. Tanaka and H. Suzuki, Carbon 10, 253 (1972).

5) G.A. Slack, J. Phys. Chem. Solids 34, 321 (1973).

6) K.M. Taylor and C. Lenie, J. Electrochem. Soc. 107, 308 (1960).

[Received April 18, 1973] 